\title{
The Application of Mental Health at Islamic Boarding Schools
}

\author{
Faisal Anwar ${ }^{1 *}$, Putry Julia ${ }^{2}$ \\ ${ }^{1,2}$ Faculty of Education and Pedagogy, Universitas Serambi Mekkah, \\ Aceh, Indonesia
}

\begin{abstract}
Islamic boarding schools are the central places for Islamic education in Indonesia. The schools have been producing Islamic leaders from time to time. Besides, they actively make an innovation so they will not be left behind. Parents sending their children into Islamic boarding schools generally expect that their children will be knowledgeable Muslim leaders in the future. However, there are factors that prevent some children from staying longer at the boarding schools. This research is a literature study with documentation research methods since the data were obtained in the form of writing, words, pictures, photos with the type of literature study by collecting, reviewing and analyzing data, documents or works related to the object of research. It was found that strict rules are among the main reasons. The students admitted that they were not mentally strong to face the rules. Other factors were loss, truancy, violence, and homosexuality. Thus, it is suggested that Islamic boarding schools should adopt the mental health perspective into their teaching and address the aforementioned issues, allowing the students to feel comfortable and be willing to stay longer at the school.
\end{abstract}

Keywords: Mental health, Islamic Boarding Schools, Application

\section{Introduction}

Islamic Boarding School is the oldest educational institutions in Indonesia. The existence of Islamic Boarding School have been estimated to be around 300-400 and has now entered all levels of society, both rich and poor society (Syafe'i, 2017). The existence of Islamic Boarding School today are not something new that because a lot of alumni of Islamic Boarding School get into their communities and engage their people to send their children to school into Islamic Boarding School. Many of those alumni have built their own Islamic Boarding School in their hometown. The rapid development of Islamic Boarding School in this country are still assumed as a "moral garage" by many people which means that students who school there are morally broken and need to be improved due to their parents have no more abilities to educate them (Hotifah, 2014).

The word "Islamic Boarding School" is derived from pe-"santri"-an, the word "santri" which means student in Javanese. The term "pondok" is derived from Arabic "funduuq" ("' فندوق") which means lodging. In Aceh especially, Islamic Boarding School is called as "dayah". A kyai is a leader in Islamic Boarding School, he who organizes all activities in Islamic Boarding School (Muhyiddin, 2018; Muzakky, 2020). While juniors are organized by their senior which are chosen by kyai. In conventional Islamic Boarding School, they are usually called "lurahpondok". The students are generally separated their lives from their parents and families. That aimed to teach them how to live independently. There are some elements of Islamic Boarding School that distinguish them with other educational institutions, namely : (1) pondok where student stay, (2) santri are learners, (3) mosque : worship facilities and center of activities, (4) kyai : a figure or someone who is highly educated in religious education, (5) classic book: as the main references in Islamic literatures (Hanurawan, 2012).

Indonesian minister of religious affair, in constitution no. 3 year 1997 divided the types of Islamic Boarding School into 4 types, namely: 1) Islamic Boarding School with A type, where all students study and stay in the dormitory in Islamic Boarding School with traditional 
method of teaching. 2) Pesatren with type B, Islamic Boarding School that organize teaching classically and the teachings are usually an application which taught in certain times. 3) Islamic Boarding School with type C, Islamic Boarding School is only a lodge while the students schools outside Islamic Boarding School (in madrasah or other schools), kyai only oversee them as their instructor. 4) Islamic Boarding School with type D, this Islamic Boarding School organize boarding school system and school or madrasah system at the same time (Tolib, 2015).

From those 4 types of Islamic Boarding School mentioned above, it seems that only type A may not belong to Islamic Boarding School modern category, event in the current context, it is not easy to classify type of traditional and modern Islamic Boarding School. However, nowadays there are a lot of conventional Islamic Boarding School which are taught with scientific methodology that are better than Islamic Boarding School modern (Indra, 2021).

Modern Islamic Boarding Schools tried to integrate the teaching between traditional and modern style. The formal teaching with classic style (teaching in the classroom) and integrated curriculum were adopted with certain adjustments. The dichotomy of religion and general subjects are eliminated. Both field of subjects are equally taught but with the domination of religious subjects. The used system in modern Islamic boarding schools are called Mu allimin(Ali, 2015).

Islamic boarding schools have been experiencing a significance transformation whether in education system or in instructional elements. Islamic boarding school have been well organized with a very neat management and administration and it's teaching system have been conducted with equal proposition between religious education and general education, and well mastery over Arabic and English (Fatmawati et al., 2020; Tolib, 2015).

Since the mid 1970's Islamic boarding Schools has been developing and having formal education which consisting of elementary schools, middle school up to university level and it has applied the basis of management (Rohmat, 2017).

This study will elaborate problems that often occur in boarding schools and it's mental health effect to students. And will give applicable steps in giving service to keep student mental health that caused by the arisen problems in boarding school.

\section{Research Method}

This research was literature research with documentation method. The collected data were taken from manuscripts or articles from various journals. In addition, articles whichwere published by various journals, books, webs, online newspapers that had something to do with the topic of the research. The main reference of this study was taken from a book entitled mental health written by Kartika Sari Dewi. The collected data then analyzed with descriptive analysis method.

\section{Results and Discussion}

\section{A. Students life in Islamic Boarding Schools}

Dormitory is the main place for students to stay in boarding schools. About $2 / 3$ students life has been spent there. Their lives in dormitory are organized with strict discipline in such a way (Afiati, 2018). There they are organized from waking up to going to bed. The rules in Islamic boarding schools consists of several chapters, they are (Musolin, 2018):

a. Student's rights and obligation

There are student's rights and obligation in boarding school, as the proper regulation which must be applied such as, all students are obligated to stay in boarding school and 
must have student ID, to watch and take care of stuffs that exist there, disciplined in learning and obey to the written and unwritten rules in boarding school, to keep clean, health and good character, to do the given task from boarding school well, to obey all the given rules from teachers, to follow the teaching schedule. All students must join in all Islamic activities held by boarding school.

b. The Study Time

The time for studying and exam are decided on schedule. Wirid is held on every Monday night, doahadad is held on every Wednesday. On Friday night is time for practicing public speaking in bilingual. On odd semester is usually held training for imam and on even semester is held training for khatib

c. Studying

The proses of studying is hoped to have good character to teacher and companions, to achieve the goal and useful knowledge than the good characters is the important key, the students ' characters in studying are : to do study based on the determined schedules, after magrib 19.00-21.00 and after shubuh 05.00:06.30, to behave politely to teachers and fellows, not to welcome guests during the school, not to have gadgets and not to share recordings without the permission from teachers.

d. In the bedroom

They should behave politely even in the bedroom among their fellows, they are some rules that must be obey in the bedroom, they are: they have to keep, take care of and maintain the cleanliness of their room, to obey rooms' rules, not have exercises in the bedroom. They must dress and cover genital neatly. Not to have long-haired for female students, not to put on tight clothes, to make bed and to pray in congregation in their room. They also must use water orderly, not to take long in the bathroom and not to leave clothes behind.

\section{e. Prayer}

Praying 5 times are compulsory to every moslim. However, to do it in congregation is sunnah muakad. In Islamic boarding schools to pray in congregation are obligated only on three times that to adjust students`activites. They are: shubuh, isya and magrib.

f. Get dressed

The main purpose of getting dress is to cover genital, not to follow the trend of clothes where the genital is covered while the shape of body can be seen. Students in Islamic boarding schools are obligated to put on polite, neat dress. For male students they wear sarong while female students they wear mukena.

g. To have meal

Eating and drinking are all served in modern boarding school. They no need to cook what they have to do is only studying. They have to eat in the students restaurant and must stand in line to get their turn to get their meal. Every student has the same ration of the menu. Every student must have their own dish and mug. Every one of them will get punishment for trespassing the rules.

h. Picket

To keep clean is next to faith, this word is clang a lot in every corner and room of schools. To keep environment clean, the school need to organize and take turn every student to clean the school, dormitory, mosque. Especially on Friday, all students are involved in mutual assistance in keeping clean.

i. Taking a permission

Every student at Islamic boarding school when they want to leave school for a while or for a long time they need to take a permission from guidance teacher. Leaving school without any permission is a big mistake in boarding school. That because the schools have full responsibility to watch their students. 
Every Islamic boarding school has different rules form one to another. Thus rules in one boarding schools sometimes don't apply to other schools. This to show the characteristics of the school. However, the purpose of the rules are to organize students in order to get used to rules in every activity at schools.

\section{B. Punishment for the Rules Breakers}

Punishment in boarding school is as a prevention effort in order to students not to act beyond limits. However, the rules in boarding school have been set still there many students break it. (Ma`arif \& Kartiko, 2018).

Therefore, a repressive punishment is necessary so they will not repeat the same mistake in the future. There are some kinds of punishment for those who break the rules. They are (Dalimunthe, 2020; Ma`arif \& Kartiko, 2018) :

1. Warning and advice

Penalty will be given to the students who break the rules in boarding school. The punishment will not be given punctually but guidance teacher firs will verify how many mistakes have been done. If the student did a mistake for the first time he will be warned only, and the effective warn is better to give after doing the mistake.

2. Educational and administrative punishments

When the warn can not make a student realize about the done mistakes even he will do the same mistakes again and again then he will be given an educational punishment such as : reciting shalawat in front of kyai, reciting manaqib for several hours, reciting nadham and so forth. The educational punishments are usually given altogether with administrative punishment namely to inform his parent about the done mistakes.

3. Social punishments

Students who break schools' rules in the moderate level, such as to skip the school for several times, go home without any permission form guidance teacher, and smoke inside the school area they will be given social punishment such as cleaning the bathroom in the school, standing before all student with the shaved head and so on.

4. Material punishments

Material punishments are sometimes applied to the rulestrespassers. They have to pay some money to buy cements, cleaners, brooms, trash bins.

5. Physical punishments

The last alternative in giving punishment is physical punishment. The punishment such as beating in non-dangerous areas of the body such as : beating on palm, jogging for several minutes, beating on calf, squat, standing under the sun and many more. Those last punishment are usually given because of stealing, going home without permission, smoking. They are offered for several punishment, it could be physical punishments, social punishments and material punishment while for the social and material punishments can be doubled that because not all students welcome with the physical punishment for some excuses.

\section{C . The common problems occur at boarding schools.}

a. Assimilation

Many students particularly new students have problem in assimilation, they are not able to follow lesson in the classroom, not able to stay in dormitory because they are not accustomed to stay away far from their parents (Yusniar, M. Abidin, Astuti, 2005). Due to not being able to assimilate with new circumstance they rarely hang out with friends, they love to seclude, to daydream and sometimes cry, rarely eat, to be silent a lot, not able to follow the lesson, have no interest, not participate in group, homesick feeling. Those what make new students will not stay long at boarding schools (Aulia, D., \& 
Kustanti, 2019).

b. Bullying

Bullying that occur at boarding schools are both verbal and non verbal. Verbal bullying they are : swearing, teasing, yelling, creating negative labels. While non verbal bullying such as :hitting, kicking, damaging his friend's belongings, forcing will. The victims of bullying usually are juniors and physically weak, while the subjects are usually considers themselves stronger, bigger and they usually love to show aggressiveness(Nashiruddin, 2019).

c. Smoking

Although the students live at schools are always supervised by the teacher guidance, there still who some. they smoke in certain places and times such as above the ceiling, behind the dormitory, in a place that is rarely passed by other students. their reason initially was trial and error and a friend's invitation (Anugrahyanti, 2017).

d. Skipping School

Skipping or intentionally leaving class is a common phenomenon in Islamic Boarding Schools. There are many reasons why they don't come to class in various ways. There are those who leave the class for only 1 subject because they are not interested in the lesson or do not like the teacher who teaches them, some pretend to be sick or sick and just lie in the dorm but play football in the afternoon. There are also those who ask to be picked up by their parents or guardians for various reasons and will return after one week or one month. And this is usually for new students or students who violate a lot (Amyani, 2012).

e. Violence

Violence is also common in Islamic Boarding Schools. Even though the Islamic Boarding School has banned various forms of violence, acts of violence within the Islamic Boarding School are still common. The reactions displayed by the students are silent, cry, and fight if the perpetrators of violence are friends (fellow students). The impact on children that arises from acts of violence is the impact in the short and long term. The short-term impact includes physical and psychological impacts, while the long-term impact is the birth of new perpetrators of violence in Islamic Boarding School boarding schools by teachers who have been in the cottage for decades and have been junior students (Setyawati, 2010).

f. Theft

The phenomenon of loss or theft is the most common phenomenon among students. The motives of the perpetrators in stealing vary. There are those who steal because of needs or habits that have been brought from home. The method is different. Some took the theme's wardrobe, some took the theme's items or clothes from the clothesline. Some take their friends' sandals and shoes and store them in their closet (Munthe, 2017).

g. Homosexuality

In addition to the cases above, the least heard is homo or lesbian behavior that occurs in Islamic Boarding Schools. Even though Islamic Boarding School is a religion-based school, homo or lesbian behavior sometimes occurs in Islamic Boarding Schools. This behavior usually starts with the closeness between junior and senior, occurs between juniors and seniors with the victims being letting, mentoring, and entitlement (Nur, 2017; Rahmatullah, 2019). This homosexual behavior can be manifested in various forms such as grabbing, masturbation, oral sex, and anal practice (Nur, 2017).

\section{The Application of Metal health to Students}

a. Adjustment and Personal Growth

Adjustment and growth is changing ourselves with our environment as a way of 
relieving our needs (Dewi, 2012). It can be divided into two parts. Adaptive dan adjustive. a) Adaptive is a form of adjustment commonly known as adaptation The nature of this form of adjustment is bodily, which means that all kinds of changes that occur in the bodily process are solely to adapt to environmental conditions. Example. When a person feels hot then he will look for a cooler to reduce or eliminate the heat. $b$ ) Adjustive is psychological in nature, which means adjusting to all kinds of behavior in an environment where this environment is well organized by norms. For example, when we go to mourn our neighbors or relatives who are grieving, our faces will automatically be set to show a sad or sad face as a form of adjustment to the sadness experienced by that person (Sobur, 2010).

b. Self-Concept

Self-concept is the overall impression and awareness that one has about oneself, including all perceptions about me (personal) and I (possessions outside of oneself), along with their feelings, beliefs, and values. Self-concept influences the way a person perceives, evaluates, and behaves (Putri Anggraini, 2019). In its application, a person can do this by measuring himself through a self-concept scale to find out where his strengths and weaknesses are so that he can accept his nature or improve it.

Example of Self-Concept Scale (Rathus. S.A \& Nevid, 2007) :

\begin{tabular}{|l|l|l|l|l|l|l|l|l|}
\hline & 1 & 2 & 3 & 4 & 5 & 6 & 7 & \\
\hline Honest, Sincere & & & & & & & & Not honest, not sincere \\
\hline Independent & & & & & & & & Depend \\
\hline Religious & & & & & & & & Not Religious \\
\hline Selfish & & & & & & & & Not selfish \\
\hline
\end{tabular}

\section{c. Emotion}

Emotion comes from Latin which means"move out". Emotion is a complex state of alertness which includes sensation (inside part) \& expression (outside part). which is the power to motivate individuals to act (Lestari, 2015). In dealing with emotional problems that often change, it can be done by managing the emotions that have been written by Thayer.

Six strategies for managing mood, ranked according to perceived success (Thayer, 1996)

\begin{tabular}{|c|c|c|}
\hline No & Strategies & Examples \\
\hline 1 & Active emotional management & $\begin{array}{l}\text { Relaxation, stress management, } \\
\text { engaging in cognitive activities, } \\
\text { sports }\end{array}$ \\
\hline 2 & $\begin{array}{l}\text { Looking for fun activities and } \\
\text { distractions }\end{array}$ & $\begin{array}{l}\text { Engage in interesting activities } \\
\text { such as humor and sharing } \\
\text { hobbies }\end{array}$ \\
\hline 3 & Withdraw, and dodge & $\begin{array}{l}\text { Alone, avoiding people who } \\
\text { cause bad emotions. }\end{array}$ \\
\hline 4 & Social Support and giving gifts & $\begin{array}{l}\text { Talking to someone, engaging in } \\
\text { emotional activities. }\end{array}$ \\
\hline 5 & Passive emotional management & $\begin{array}{l}\text { Watch } T V \text {, drink coffee, eat, take } \\
\text { a rest. }\end{array}$ \\
\hline 6 & Immediate tension reduction & take drugs. \\
\hline
\end{tabular}


Another way that can also be done in managing negative emotions (e.g., anger) is by "I" Message

Example from "I" Message (Dewi, 2012).

\begin{tabular}{|c|c|c|c|}
\hline $\begin{array}{l}\text { Non-judgmental } \\
\text { Description of } \\
\text { Person's } \\
\text { Behavior }\end{array}$ & $\begin{array}{l}\text { Concrete Effects } \\
\text { on Me }\end{array}$ & $\begin{array}{l}\text { My Feeling } \\
\text { About It }\end{array}$ & $\begin{array}{l}\text { What I'd Prefer } \\
\text { the } \\
\text { Person to Do }\end{array}$ \\
\hline $\begin{array}{l}\text { 1. If you don't } \\
\text { complete what you } \\
\text { promised to do }\end{array}$ & $\begin{array}{l}\text { Then I have to } \\
\text { do in addition } \\
\text { to my tasks. }\end{array}$ & $\begin{array}{l}\text { and I feel } \\
\text { annoyed. }\end{array}$ & $\begin{array}{l}\text { I wish you would } \\
\text { do what do what } \\
\text { you promised. }\end{array}$ \\
\hline $\begin{array}{l}\text { 2. Each time you } \\
\text { criticize my work } \\
\text { without telling me } \\
\text { what I'm doing } \\
\text { wrong }\end{array}$ & $\begin{array}{l}\text { I don't know } \\
\text { how to improve } \\
\text { it. }\end{array}$ & $\begin{array}{l}\text { and I feel } \\
\text { frustrated and } \\
\text { resentful. }\end{array}$ & $\begin{array}{l}\text { Tell me what I'm } \\
\text { doing wrong, so I } \\
\text { can correct it. }\end{array}$ \\
\hline $\begin{array}{l}\text { 3. When you change } \\
\text { your mind at the } \\
\text { last minute }\end{array}$ & $\begin{array}{l}\text { It's too late to } \\
\text { make other } \\
\text { plans. }\end{array}$ & $\begin{array}{l}\text { and I feel } \\
\text { angry and } \\
\text { disappointed. }\end{array}$ & $\begin{array}{l}\text { Give me more } \\
\text { advance notice } \\
\text { you } \\
\text { think things may } \\
\text { not work. }\end{array}$ \\
\hline
\end{tabular}

c. Psychological wellness

Psychological wellness is an individual condition that leads to adequate development and mental abilities that have a suitable function, so that individuals are able to develop their mental abilities better (Jamil, 2016). In a psychological wellness, psychological well-being needs to be built and developed psychological well-being. Self-development that can be done in the form of:

a) To improve communication, active listening skills, empathy, verbal \& non-verbal skills assertive. 1) to use effective humor. 2) To fix conflict management skills. 3) To take a proactive approach in life, consists of : 1 . To build mental images, 2 . To receive mental image, 3 . To strive to gain new experience. 4) The arranged mental image used as pattern or references in activities (Hahn, D.B, \& Payne, 2003).

b) Interpersonal Relationship

Interpersonal relationships are relationships that consist of two or more people who depend on each other which are built with awareness and willingness that use a consistent pattern of interaction. (Dian Wisnuwardhani, 2012; Hasibuan, 2009). There are several kinds of models in the practice of interpersonal relationships. Among the existing models can be considered to improve students' interpersonal relationship skills. They are: 1 . Transaction consists of Complimentary (between ego state anad parallel), 2. crossed dan ulterior (camouflage), 3. Stroke

1. Transaction

A transaction is a communication between two individuals who are involved in giving a stimulus. 
a. Complimentary

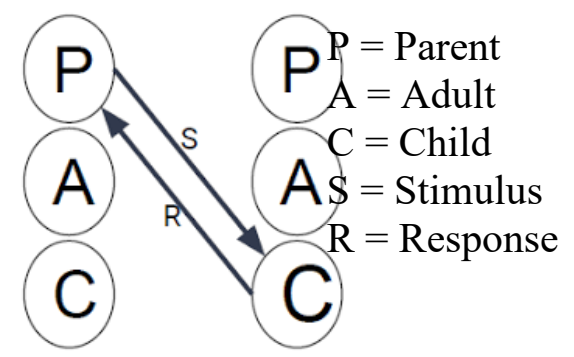

$\mathrm{P}=$ What time is it?

$\mathrm{C}=\mathrm{It}$ is 8

$\mathrm{P}=$ Where are you going?

$\mathrm{C}=\mathrm{I}$ am going to buy fried rice

b. Crossed

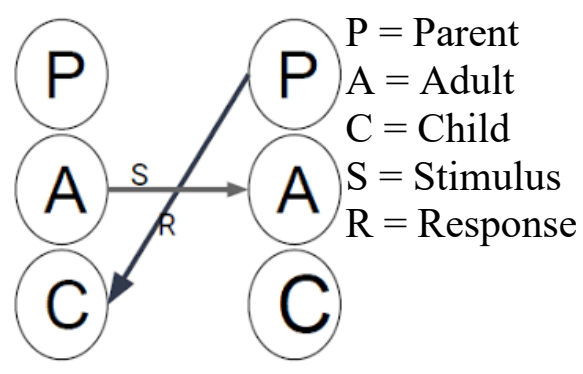

$\mathrm{A}=$ What time is it?

$\mathrm{P}=$ you can buy your own watch

$\mathrm{A}=$ Where you've been?

$\mathrm{P}=$ mind your business

c. ulterior

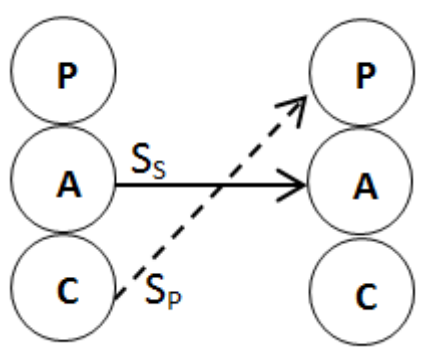

$\mathrm{P}=$ Parent

A =wanna ice cream?

$\mathrm{A}=$ Adult

$\mathrm{C}=$ no, I am OK (delivered

$\mathrm{C}=$ Child rather quietly, not even

$\mathrm{Ss}=$ Stimulus level social heard, but eyes on the ice cream )

$\mathrm{Sp}=$ Stimulus

level

Psychology

2. Stroke

Stroke is the attention or touch given to another individual. Positive strokes are fun for others, for example: a smile, a hug, a pat on the shoulder. Negative stroke is an unpleasant feeling, for example: scolding, frowning face.

\begin{tabular}{|l|l|l|}
\hline \multirow{2}{*}{ Conditional } & 1. Positive & 2. Negative \\
\cline { 2 - 3 } & $\begin{array}{l}\text { "If your are smart, you are } \\
\text { my son..." }\end{array}$ & $\begin{array}{l}\text { "I will punish you } \\
\text { because you beat you } \\
\text { brother" }\end{array}$ \\
\hline Unconditional & Unconditional Love & $\begin{array}{l}\text { "are you stumbled? What } \\
\text { a bad stone..." }\end{array}$ \\
\hline
\end{tabular}

3. Stress \& Coping and adjustment to stress

Stress is known as the interaction between a person's coping ability and environmental demands. It is a psychobiological process Stimuli that harm physically and psychologically are threatening, then cause anxiety reactions (Andriyani, 2019). There are several types of psychological stress that are often faced by everyone, namely: 1) Pressure, 2) Frustration, 3) Conflict, 4) Anxiety.

Stress will not just go away because everyone will face problems like the ones mentioned above. However, stress can be managed in such a way that the stress 
faced is not sustainable or becomes a mental burden. There are at least 4 easy ways to deal with stress. 1) Self-shooting, 2) Distraction, 3) Opposite Action, 4) Emotional Awareness, 5) Mindfulness, 6) Crisis Plan.

\begin{tabular}{|l|l|}
\hline Coping Types & Probably can be done \\
\hline $\begin{array}{l}\text { Self-Soothing } \\
\text { Facing yourself with the 5 senses }\end{array}$ & $\begin{array}{l}\text { 1. Touching something (stress ball, pets) } \\
\text { 2. Hearing something (music, listening to } \\
\text { the Quran, lectures) } \\
\text { 3. Seeing something (humorous film) } \\
\text { 4. Smell something (lotions, perfumes, } \\
\text { flowers) }\end{array}$ \\
\hline $\begin{array}{l}\text { Distraction } \\
\text { Take your mind off the problem for a } \\
\text { moment. }\end{array}$ & $\begin{array}{l}\text { Playing puzzles, reading books, art, sewing, } \\
\text { crosswords, }\end{array}$ \\
\hline $\begin{array}{l}\text { Opposite Action } \\
\text { Doing something contrary to the inner } \\
\text { voice that has positive emotions }\end{array}$ & $\begin{array}{l}\text { 1. Something inspiring (see pictures } \\
\text { containing motivational sentences) }\end{array}$ \\
\hline $\begin{array}{l}\text { Emotional Awareness } \\
\text { Emotional awareness is a tool to } \\
\text { identify and express feelings }\end{array}$ & Writhny movies, humor books, TV) list emotions \\
\hline $\begin{array}{l}\text { Mindfulness } \\
\text { Mindfulness is a tool to decide and tidy } \\
\text { up ourselves in this moment }\end{array}$ & Meditation, dhikr, breathing exercises \\
\hline $\begin{array}{l}\text { Crisis Plan } \\
\text { Crisis plan is the last step that should be } \\
\text { taken immediately if coping efforts can't } \\
\text { help }\end{array}$ & Close family/friends, therapist, psychiatrist. \\
\hline
\end{tabular}

\section{Conclusion}

The existence of Islamic Boarding Schools become part of the civilization of education in Indonesia. Islamic Boarding Schools continue to grow from year to year and continue to produce community cadres. The high interest of prospective students and prospective guardians of students shows that the enthusiasm of the Indonesian people to send their children to Islamic Boarding School is very large. However, life at the Islamic Boarding Schools is not what most people imagine. There are many rules and problems occur at the Islamic Boarding Schools environment because life there is a congregational life which need to be regulated in such a way so that it remains orderly.

The problems that occur will continue to occur every year and even every month and result in victims of the incident. Therefore, Islamic Boarding Schools need to develop their educational model in providing maximum services for mental health services to maintain the determination of their students to feel at home at boarding schools and become as expected by their parents.

\section{References}

Afiati, N. S. (2018). Kualitas Kehidupan Sekolah Dan Disiplin Pada Santri Asrama Pondok Islamic Boarding School. Insight: Jurnal Ilmiah Psikologi, 20(1), 15. https://doi.org/10.26486/psikologi.v20i1.630

Ali, M. (2015). Model Pendidikan Toleransi Di Islamic Boarding School Modern Dan Salaf. Jurnal Pendidikan Agama Islam, 03(01), 82-108. 
https://media.neliti.com/media/publications/118211-ID-model-pendidikan-toleransi-diIslamic Boarding School.pdf

Amyani, S. (2012). Hubungan antara Kepercayaan diri dengan Kemandirian Santri Islamic Boarding School Tahfizh Sekolah Daarul Qur'an Internasional Bandung [Universitas Islam Syarif Hidayatulllah]. http://repository.uinjkt.ac.id/dspace/handle/123456789/21645

Andriyani, J. (2019). Strategi Coping Stres Dalam Mengatasi Problema Psikologis. AtTaujih: Bimbingan Dan Konseling Islam, 2(2), 37. https://doi.org/10.22373/taujih.v2i2.6527

Anugrahyanti. (2017). PERILAKU MEROKOK SANTRI DI PONDOK ISLAMIC BOARDING SCHOOL MODERN DARUL FALAH ENREKANG [Universitas Hasanuddin Makassar]. http://digilib.unhas.ac.id/uploaded_files/temporary/DigitalCollection/Yzc0NjMxODRk ODdiYzIyYjcwYmQzMjQ0MmR1MjgzMTEzYTk0M2E4MQ==.pdf

Aulia, D., \& Kustanti, E. R. (2019). HUBUNGAN ANTARA EFIKASI DIRI AKADEMIK DENGAN PENYESUAIAN DIRI PADA SISWA BOARDING SCHOOL DI MADRASAH TSANAWIYYAH NU ASSALAM DAN MADRASAH TSANAWIYYAH AMTSILATI (Doctoral dissertation, Undip). http://eprints.undip.ac.id/73537/

Dalimunthe, S. A. (2020). BENTUK HUKUMAN TERHADAP KENAKALAN SANTRI DI ASRAMA DARUL IKHLAS KECAMATAN PANYABUNGAN KOTA KABUPATEN $M A N D A I L I N G$ NATAL [Institut Agama Islam Negeri]. http://etd.iainpadangsidimpuan.ac.id/5921/1/1530200056.pdf

Dewi, K. S. (2012). Buku Ajar Kesehatan Mental.

Dian Wisnuwardhani, S. F. M. (2012). Hubungan Interpersonal. Salemba Humanika.

Fatmawati, F., Katon, G., Sulistiyono, R. N., \& Diany, S. I. (2020). Peran Islamic Boarding School Modern Terhadap Pembentukan Karakter Kepemimpinan Santri. AL-FIKR: Jurnal Pendidikan Islam, 6(1), 27-33. https://doi.org/10.32489/alfikr.v6i1.66

Hahn, D.B, \& Payne, W. . (2003). Focus on Health, 6th edt. New York: McGraw-Hill companies.

Hanurawan, F. (2012). Strategi Pengembangan Kesehatan Mental Di Lingkungan Sekolah. PSIKOPEDAGOGIA Jurnal Bimbingan Dan Konseling, 1(1). https://doi.org/10.12928/psikopedagogia.v1i1.2572

Hasibuan, M. (2009). Manajemen Sumber Daya Manusia. Edisi Revisi. Salemba Humanika.

Hotifah, Y. (2014). Empowering Santri dalam Mengatasi Permasalahan Pembelajaran di Islamic Boarding School Melalui Model Peer Helping Berbasis Kearifan Lokal Islamic Boarding School. Jurnal Personifikasi, 5(1), 19-42.

Indra, K. (2021). Strategi Penglolaan Pendidikan Pada Islamic Boarding School MOdern di Wilayah Aceh Besar [Universitas islam Negeri Ar-Raniry]. https://repository.arraniry.ac.id/id/eprint/17864/1/Indra Kurniawan\%2C 29173550\%2C PPs UIN\%2C PAI\%2C 085262700892.pdf

Jamil, H. (2016). Nilai-Nilai Psikologis dalam Al-Fâtihah menurut Hamka (Kajian Analisa) (Doctoral dissertation, Institut PTIQ Jakarta). https://repository.ptiq.ac.id/id/eprint/102/

Lestari, A. J. (2015). Perbandingan Kecerdasan Emotional (Emotional Intelligencse) antara Mahasiswa Input SMA Input MA Jurusan Pendidikan Fisika Fakultas Tarbiah dan Keguruan UIN Alauddin Makassar (Doctoral dissertation, Universitas Islam Negeri Alauddin Makassar). [niversitas Islam Negeri Alauddin Makassar]. http://repositori.uinalauddin.ac.id/9589/

Ma`arif, M. A., \& Kartiko, A. (2018). Fenomenologi Hukuman di Islamic Boarding School : Analisis Tata Tertib Santri Pondok Islamic Boarding School Daruttaqwa Gresik. Nadwa: Jurnal Pendidikan Islam, 12(1), 181-196. https://doi.org/10.21580/nw.2018.12.1.1862 
Muhyiddin, I. (2018). Metode Pembelajaran Sorogan dan Bahtsu Al-Masail Dalam Prestasi Belajar Santri (Studi di Pondok Islamic Boarding School Terpadu Daarul Mubtadi'in Kecamatan Jayanti Kabupaten Tangerang (Doctoral dissertation, Universitas Islam Negeri" SMH" Banten). http://repository.uinbanten.ac.id/2769/

Munthe, F. F. (2017). Penerapan Metode Ta'zir Bagi Upaya Meminimalisir Merebaknya Angka Pencurian Di Islamic Boarding School (Studi Kasus Di Islamic Boarding School Al Kautsar Al Akbar Medan) [Universitas Muhammadiyah Sumatra Utara]. http://repository.umsu.ac.id/handle/123456789/2404

Musolin, M. (2018). Manajemen Pendidikan Karakter Pada Pondok Islamic Boarding School an Nawawi Berjan Purworejo. Jurnal At-Tarbiyat: Jurnal Pendidikan Islam, 23-44. https://doi.org/10.37758/jat.v1i1.101

Muzakky, M. (2020). Strategi Pembaharuan Pendidikan Islam Di Pondok Islamic Boarding School Tarbiyatul Islam Al Falah Kelurahan Dukuh Kecamatan Sidomukti .... Skripsi. http://e-repository.perpus.iainsalatiga.ac.id/8923/

Nashiruddin, A. (2019). Fenomena Bullying Di Pondok Islamic Boarding School Al-Hikmah Kajen Pati. Quality, 7(2), 81. https://doi.org/10.21043/quality.v7i2.6295

Nur, G. N. S. (2017). IDENTITAS DAN HOMOSEKSUALITAS DI ISLAMIC BOARDING SCHOOL: STUDI KASUS DI PONDOK ISLAMIC BOARDING SCHOOL AS-SAKAN DAN ALUMNI SANTRI DARI ISLAMIC BOARDING SCHOOL DI JAWA BARAT [Universitas https://repository.unpad.ac.id/frontdoor/index/index/year/2020/docId/27792

Putri Anggraini, W. (2019). KONSEP DIRI PEMUDA PENGANGGURAN DI DESA PEMATANG BALAM KECAMATAN HULU PALIK KABUPATEN BENGKULU UTARA (Doctoral dissertation, IAIN BENGKULU).

Rahmatullah, A. S. (2019). Homoseksual Kaum Santri di Islamic Boarding School (Antara Patologi Sosial dan Perilaku Abnormal). Al-Murabbi, 6(1). https://doi.org/10.53627/jam.v6i1.3633

Rathus. S.A \& Nevid, J. . (2007). Psychology and The Challenges of Life: Adjustment in the new millenium (ten edtiti). John Wiley and Sons.

Rohmat, N. (2017). Peran Kyai Dalam Upaya Pembaruan Pendidikan di Pondok Islamic Boarding School Tri Bhakti At-Taqwa Rama Puja Raman Utara Lampung Timur [Isntitut Agama Islam Negeri https://repository.metrouniv.ac.id/id/eprint/2969/1/Skripsi IAIN Metro 21.pdf

Setyawati, I. (2010). KEKERASAN TERHADAP ANAK (Studi Deskriptif Tentang Bentuk Kekerasan, Reaksi, dan Dampak Kekerasan Terhadap Anak di Pondok Islamic Boarding School). [Universitas Airlangga]. http://repository.unair.ac.id/id/eprint/16887

Sobur, A. (2010). Psikologi Umum. Pustaka Setia.

Syafe'i, I. (2017). PONDOK ISLAMIC BOARDING SCHOOL: Lembaga Pendidikan Pembentukan Karakter. Al-Tadzkiyyah: Jurnal Pendidikan Islam, 8(1), 61. https://doi.org/10.24042/atjpi.v8i1.2097

Thayer, R. E. (1996). The origin of everyday moods: Managing energy, tension, and stress. Oxford University Press.

Tolib, A. (2015). PENDIDIKAN DI PONDOK ISLAMIC BOARDING SCHOOL MODERN Oleh: Dr. Abdul Tolib. Jurnal Risaalah, 1(1), 60-66. http:/jurnal.faiunwir.ac.id

Yusniar, M. Abidin, Astuti, T. . (2005). Penyesuaian Diri Santri Putri TerhadapKehidupan Islamic Boarding School: Studi Kualitatif pada Madrasah Takhasusiah Pondok Islamic Boarding School Modern Islam Assalam Surakarta. Jurnal Psikologi Undip, 2, 10-17. 